\title{
Filariasis Limfatik di Kelurahan Pabean Kota Pekalongan
}

\section{Tri Ramadhani*}

\begin{abstract}
Abstrak
Filariasis limfatik masih merupakan masalah kesehatan masyarakat di Indonesia, khususnya di Kota Pekalongan. Hal ini ditandai dengan semakin meningkatnya angka mikrofilaria dan perluasan daerah dengan kasus filariasis limfatik. Tujuan penelitian adalah untuk mengetahui situasi filariasis limfatik di Kelurahan Pabean Kota Pekalongan. Penelitian ini meliputi penduduk dan agent, dalam periode sekitar enam bulan (Juli-Desember 2007) dengan disain studi cross sectional. Pada penelitian ini dilakukan pemeriksaan klinis, survei darah jari dan identifikasi parasit penyebab filariasis limfatik. Hasil penelitian menunjukkan angka mikrofilaria $(3,4)$ angka kesakitan akut filaria $(0,4 \%)$ yang tinggi, tetapi angka kesakitan kronis filaria rendah $(0,00 \%)$. Parasit penyebab filariasis di Kelurahan Pabean adalah jenis Wuchereria bancrofti dengan kepadatan rerata mikrofilaria yang tinggi. Pengendalian filariasis limfatik di Kelurahan Pabean perlu dilakukan dengan pengobatan massal dan perubahan perilaku masyarakat.
\end{abstract}

Kata kunci : Filariasis limfatik, kelurahan pabean, mikrofilaria.

\begin{abstract}
Lymphatic filariasis is still being a public health problem in Indonesia, especially in Pekalongan district. This problem marked by the increasing rate of microfilaria and areas with lymphatic filariasis. The aim of this study is to know the epidemiologic situation of lymphatic filariasis in Pabean village Pekalongan district. The research was a cross-sectional design and covered host and agent within the period of July-Desember 2007. Data were collected through clinical survey of acute and chronic filariasis symptoms, blood survey and identification of lymphatic filariasis parasite. The result showed that microfilaremia rate was $3,4 \%$, acute disease rate (ADR) $0,4 \%$ and the chronic disease rate (CDR) 0,00\%. The average of microfilaria density in $1 \mathrm{ml}$ blood was 465,63 . Based on microfilaremia identification in the blood, the lymphatic filariasis agent in Pabean village is Wuchereria bancrofti type. Lymphatic filariasis control in Pabean village need to focused on Mass Drug Administration (MDA) and community behavior for healthy life.
\end{abstract}

Key words : Lymphatic filariasis, pabean village, microfilaria. 
Di Indonesia, sampai kini filariasis saluran getah bening (lymphatic filariasis) masih menjadi masalah kesehatan masyarakat yang penting, terutama di daerah pedesaan dan daerah perkotaan kumuh. Sampai tahun 2004, di Indonesia diperkirakan enam juta orang terinfeksi filariasis limfatik dan dilaporkan lebih dari 8.243 diantaranya menderita klinis kronis filariasis terutama di pedesaan. Filariasis tersebut yang disebabkan oleh Brugia malayi, Brugia timori, Wuchereria bancrofti tipe perkotaan dan pedesaan mengancam sekitar 20 juta penduduk Indonesia. Penyakit yang bersifat menahun ini tidak menyebabkan kematian, tetapi menyebabkan kecacatan, kemiskinan dan berbagai masalah sosial yang lain. ${ }^{1}$ Apabila tidak diobati, penyakit ini dapat menimbulkan cacat seumur hidup dan penderita tidak dapat bekerja secara optimal, sehingga menjadi beban keluarga serta merugikan masyarakat dan negara. Selain itu, penderita akan mengalami kerugian ekonomi sekitar $17,8 \%$ dari biaya rumah tangga atau 32,3\% dari biaya makan keluarga. ${ }^{2}$

Kota Pekalongan di Provinsi Jawa Tengah yang terletak dekat Kabupaten Pekalongan merupakan daerah endemis filariasis. Kota Pekalongan terdiri dari 4 Kecamatan meliputi Pekalongan Utara, Pekalongan Barat, Pekalongan Timur dan Pekalongan Selatan. Sampai bulan Mei 2004, dilaporkan 12 kasus filaria kronis yang tersebar di 11 Kelurahan dalam 3 Kecamatan yaitu Kecamatan Pekalongan Barat (Kelurahan Tegalrejo, Kramatsari, Medono, Bendan), Kecamatan Pekalongan Utara (Kelurahan Bandengan, Krapyak Lor, Kraton Kidul, Panjang Wetan), dan Kecamatan Pekalongan Timur (Kelurahan Landungsari, Sugih Waras, Klego). ${ }^{3}$

Pada tahun 2004, survei darah jari (SDJ) yang dilakukan di Kelurahan Pabean Kecamatan Pekalongan Utara dan Pasirsari Kecamatan Pekalongan Barat menemukan mikrifilariua positif $m f$ rate $2,34 \%$ dan $0 \%$. Pada tahun 2005, survei darah jari di empat kelurahan menemukan angka $m f$ rate di Kelurahan Kramatsari Kecamatan Pekalongan Barat (0,38\%), Kelurahan Bandengan Kecamatan Pekalongan Utara $(2,38 \%)$, Kelurahan Tirto Kecamatan Pekalongan Barat (0,40\%) dan Kelurahan Tegalrejo Kecamatan Pekalongan Barat $(2,40 \%)$. Spesies mikrofilaria yang ditemukan seluruhnya adalah jenis Wuchereria bancrofti. ${ }^{3}$ Pada Februari 2007, survei darah jari di Kelurahan Bumirejo Kecamatan Pekalongan Barat menemukan mf rate $(5,48 \%)$. Hal ini menunjukkan kecenderungan peningkatan distribusi kasus filariasis limfatik di Kecamatan Pekalongan Barat. Tujuan dari penelitian ini adalah mengetahui angka mikrofilaria ( $m f$ rate), spesies cacing penyebab filariasis, angka kesakitan akut dan kronis serta kepadatan rerata mikrofilaria.

\section{Metode}

Jenis penelitian yang digunakan adalah penelitian observasional dengan desain cross sectional. Penelitian dilaksanakan di Kelurahan Pabean, Kecamatan Pekalongan Utara Kota Pekalongan, Provinsi Jawa Tengah. Populasi penelitian adalah seluruh penduduk di Kelurahan Pabean, sedangkan sampel penelitian meliputi seluruh penduduk yang bersedia dan berhasil diambil sediaan darahnya yang berada di lokasi penelitian sejumlah 500 orang. Pengambilan sediaan darah dilakukan pada malam hari mulai jam 20.00 dengan metode lingkaran obat nyamuk dimulai dari rumah penderita kronis, apabila jumlah penduduk desa kurang dari 500 orang, sampel ditambah dengan penduduk desa lain yang berdekatan dalam kecamatan yang sama. ${ }^{4}$ Pemeriksaan darah dilakukan dengan cara biasa yaitu tusuk jari dengan cara ujung jari kedua, ketiga atau keempat dibersihkan dengan kapas alkohol 70\% setelah kering ditusuk dengan lancet sampai darah menetes keluar, tetesan darah pertama yang keluar dihapus dengan kapas kering, kemudian darah berikutnya dihisap dengan tabung kapiler tanpa heparin sebanyak $60 \mathrm{~mm} .^{3}$ Darah kemudian ditiupkan ke atas kaca benda, dilebarkan sehingga membentuk sediaan darah tebal dan berbentuk oval dengan diameter $2 \mathrm{~cm}$. Setelah dikeringkan selama 1 malam dengan cara penyimpanan yang aman dari serangga, keesokan harinya di-hemolisis dengan air selama beberapa menit sampai warna merah hilang, dibilas lagi dengan air dan dikeringkan. Sediaan darah difiksasi dengan methanol selama 1-2 menit dan dikeringkan, kemudian diwarnai dengan Giemsa yang telah dilarutkan di dalam cairan buffer $\mathrm{pH}$ 7,2 (1 tablet buffer dilarutkan dalam $100 \mathrm{cc}$ air aquadest) dengan perbandingan 1:14 selama 15 menit. Kemudian dibilas dengan air bersih dan dikeringkan. Sediaan darah diperiksa di bawah mikroskop dengan pembesaran rendah $(10 \times 10)$ untuk menentukan jumlah mikrofilaria, pembesaran tinggi $(10 \mathrm{x} 40)$ untuk menentukan jenis/ spesiesnya. Jumlah mikrofilaria per unit volume darah yang diambil $\left(60 \mathrm{~mm}^{3}\right)$ dihitung untuk mengetahui ratarata kepadatan mikrofilaria setiap $60 \mathrm{~mm}^{3}$ sediaan darah. Hasil penemuan dicatat pada formulir untuk menentukan angka mikrofilaria ( $m f$ rate), kepadatan rerata mikrofilaria, angka kesakitan akut $(A D R)$ dan angka kesakitan kronis $(C D R)$.

\section{Hasil}

Kota Pekalongan berada di dataran rendah Jalur Pantai Utara Pulau Jawa, terletak pada 6050'42". 6055'44" Lintang Selatan dan 109037'55”- 109042'19" Bujur Timur dengan ketinggian \pm 1-2 meter dari permukaan air laut. Secara administrasi sebelah utara berbatas dengan Laut Jawa, sebelah timur Kabupaten Batang, sebelah barat Kabupaten Pekalongan dan sebelah selatan Kabupaten Pekalongan-Batang. Kota Pekalongan terdiri dari 4 Kecamatan, 46 Kelurahan dengan luas 
Tabel 1. Distribusi Kasus Filariasis Limfatik Akut dan Kronis

\begin{tabular}{lrrr}
\hline \multirow{2}{*}{ Kecamatan/Kelurahan } & \multicolumn{2}{c}{ Jumlah Kasus } & \\
\cline { 2 - 3 } & Akut & Kronis & Total Kasus \\
\hline Kec.Pekalongan Barat & $\mathbf{5 8}$ & $\mathbf{4}$ & $\mathbf{6 2}$ \\
Kelurahan Tirto & 2 & 0 & 2 \\
Kelurahan Tegalrejo & 11 & 1 & 12 \\
Kelurahan Kramatsari & 1 & 1 & 2 \\
Kelurahan Bumirejo & 28 & 0 & 28 \\
Kelurahan Pasirsari & 16 & 0 & 16 \\
Kelurahan Medono & 0 & 1 & 1 \\
Kelurahan Bendan & 0 & 1 & 1 \\
Kec.Pekalongan Utara & $\mathbf{1 7}$ & $\mathbf{4}$ & $\mathbf{2 1}$ \\
Kelurahan Pabean & 0 & 0 & 0 \\
Kelurahan Bandengan & 17 & 1 & 18 \\
Kelurahan Krapyak Lor & 0 & 1 & 1 \\
Kelurahan Kraton Kidul & 0 & 1 & 1 \\
Kelurahan Panjang Wetan & 0 & 1 & 1 \\
Kec.Pekalongan Timur & $\mathbf{0}$ & $\mathbf{4}$ & $\mathbf{4}$ \\
Kelurahan Landungsari & 0 & 1 & 1 \\
Kelurahan Sugih Waras & 0 & 2 & 2 \\
Kelurahan Klego & 0 & 1 & 1 \\
Kec.Pekalongan Selatan & 0 & 0 & 0 \\
Kota Pekalongan & $\mathbf{7 5}$ & $\mathbf{1 2}$ & $\mathbf{8 7}$ \\
\hline
\end{tabular}

Sumber data : Dinas Kesehatan Kota Pekalongan

wilayah 4.525 ha, sekitar 0,14\% luas wilayah Provinsi Jawa Tengah. Penggunaan tanah di Kota Pekalongan terdiri dari $32,52 \%$ tanah sawah dan $67,48 \%$ tanah kering. 5

Kasus filariasis kronis di Kota Pekalongan pada tahun 2006-2007 berjumlah 12 penderita yang tersebar 3 Kecamatan yaitu 4 penderita di Kecamatan Pekalongan Barat, 4 penderita di Kecamatan Pekalongan Utara, dan 4 penderita di Kecamatan Pekalongan Timur. Jumlah kasus klinis atau positif mengandung mikrofilaria hasil kegiatan survei darah jari sebanyak 75 penderita. Hanya Kecamatan Pekalongan Selatan yang benar-benar bebas dari kasus filariasis limfatik baik akut maupun kronis (Lihat Tabel 1).

Kelurahan Pabean dipilih sebagai lokasi penelitian dengan pertimbangan hampir semua Kelurahan di Kecamatan Pekalongan Utara dan Kecamatan Pekalongan Barat mempunyai masalah filariasis limfatik dengan $m f$ rate lebih dari $1 \%$. Kelurahan Pabean merupakan salah satu Kelurahan dari 4 Kelurahan yang ada di wilayah kerja Puskesmas Kusuma Bangsa Kecamatan Pekalongan Utara, Provinsi Jawa Tengah. Kelurahan Pabean terdiri dari 4 RW dan 13 RT. Luas wilayah Kelurahan Pabean sebesar 86,76 ha dengan batas Kelurahan, sebelah Utara dengan Kelurahan Jeruksari dan Kelurahan Kraton Lor. Sebelah Selatan berbatasan dengan Kelurahan Kramatsari dan Kelurahan Pasirsari. Sebelah Barat berbatasan dengan Kelurahan Tegaldowo dan Kelurahan Mulyorejo sedangkan sebelah Timur berbatasan dengan Kelurahan Dukuh. Selain berupa pemukiman yang dihuni oleh 3.435 jiwa, sebagian lahan diperuntukan untuk sawah dan ladang dengan irigasi teknis dan irigasi tadah hujan. Kelurahan Pabean merupakan daerah pantai dan beriklim tropis dengan kisaran suhu udara antara $29^{\circ} \mathrm{C}-31^{\circ} \mathrm{C}$, serta berada pada ketinggian 3 meter di atas permukaan laut.

\section{Survei Darah Jari}

Survei darah jari yang dilakukan di Kelurahan Pabean Kecamatan Pekalongan Utara, ditemukan 17 penduduk positif mengandung mikrofilaria dalam darah tepinya. Berdasarkan morfologi mikrofilaria yang didapatkan, parasit penyebabnya dapat diidentifikasikan sebagai Wuchereria bancrofti yang secara epidemiologi termasuk tipe perkotaan (Lihat Tabel 2).

Penderita mikrofilaremia terdistribusi di seluruh wilayah Kelurahan Pabean dan terbanyak berada di RW III yaitu sebanyak 7 penderita, 6 penderita berada di RT 01, sedangkan di RW I ada 3 penderita, RW IV 5 penderita dan terendah di RW II 2 penderita.

\section{Angka mikrofilaria (mf rate)}

Hasil anamnesis dan pemeriksaan fisik pada saat survei darah jari, pada tabel 3 dapat dilihat angka penderita filariasis akut sebesar 1\% (5 penderita) dari 500 penduduk yang diperiksa di Kelurahan Pabean yaitu adanya gejala limfangitis yang disertai dengan demam, sakit kepala, lemah tetapi kemudian hilang dan timbul kembali. Serangan akut demam ini tidak begitu nyata dirasakan oleh penduduk, sehingga pada saat pemeriksaan mereka tidak lancar dan kurang jelas menyampaikan keluhannya.

\section{Angka Kesakitan Akut dan Kronis}

Pada tabel 4 didapatkan angka kesakitan akut dengan gejala limfangitis yang disertai dengan demam, sakit kepala, lemah (ADR) $(0,4 \%)$ sedangkan angka kesakitan kronis (CDR) $0 \%$.

Pada tabel 5 dan 6 menunjukkan dari hasil anamnesis, pemeriksaan fisik dan pemeriksaan darah jari diketahui bahwa penderita mikrofilaremia tidak selalu disertai dengan kelainan klinis, sebaliknya pada penderita dengan kelainan klinis belum tentu didapatkan mikrofilaria dalam darahnya. Dengan demikian untuk penderita yang tidak menunjukkan kelainan klinis, belum tentu tidak dijumpai mikrofilaria dalam darahnya, atau sebaliknya. Keadaan ini yang banyak dijumpai di Kelurahan Pabean.

Pada tabel 5 menunjukkan dari 17 penderita mikrofilaremia yang ditemukan didapatkan 2 penderita $(11,76 \%)$ yang menunjukkan kelainan klinis akut sedangkan yang lain bersifat asimtomatik. Dapat juga dikatakan, dari 5 penderita dengan kelainan klinis fila- 
Tabel 2. Penderita Positif Mikrofilaria di Kelurahan Pabean Menurut Spesies Cacing Filaria

\begin{tabular}{|c|c|c|c|c|c|c|}
\hline \multirow{2}{*}{\multicolumn{2}{|c|}{$\begin{array}{l}\text { Umur } \\
\text { Penderita }\end{array}$}} & \multirow{3}{*}{ Alamat } & \multicolumn{4}{|c|}{ Hasil SDJ } \\
\hline & & & \multicolumn{3}{|c|}{ Spesies } & \multirow{2}{*}{$\begin{array}{c}\text { Kepadatan } \\
\text { Mikrofilaria }(60 \mathrm{\Phi l})\end{array}$} \\
\hline $\mathrm{L}$ & $\mathrm{P}$ & & B.malayi & B.timori & W.bancrofti & \\
\hline & 60 & Pabean Rt 03/IV & & & + & 65 \\
\hline 55 & & Pabean Rt 03/I & & & + & 11 \\
\hline 28 & & Pabean Rt 02/III & & & + & 27 \\
\hline & 24 & Pabean Rt 01/IV & & & + & 36 \\
\hline 34 & & Pabean Rt 03/II & & & + & 8 \\
\hline 75 & & Pabean Rt 01/III & & & + & 72 \\
\hline 9 & & Pabean Rt 01/II & & & + & 8 \\
\hline 29 & & Pabean Rt 02/I & & & + & 3 \\
\hline 63 & & Pabean Rt 02/IV & & & + & 6 \\
\hline 2 & & Pabean Rt 01/I & & & + & 3 \\
\hline & 25 & Pabean Rt 01/III & & & + & 3 \\
\hline 25 & & Pabean Rt 3/IV & & & + & 42 \\
\hline 20 & & Pabean Rt 3/IV & & & + & 67 \\
\hline & 55 & Pabean Rt 01/III & & & + & 24 \\
\hline & 65 & Pabean Rt 01/III & & & + & 71 \\
\hline 54 & & Pabean Rt 01/III & & & + & 16 \\
\hline 23 & & Pabean Rt 01/III & & & + & 12 \\
\hline
\end{tabular}

Tabel 3. Distribusi Penderita Mikrofilaremia dan Filariasis Klinis Menurut Golongan Umur

\begin{tabular}{|c|c|c|c|c|c|c|c|c|}
\hline \multirow{3}{*}{$\begin{array}{l}\text { Umur (th) } \\
\text { diperiksa }\end{array}$} & \multirow{2}{*}{\multicolumn{2}{|c|}{ Mikrofilaremia }} & \multicolumn{4}{|c|}{ Filariasis Klinis } & \multirow{2}{*}{\multicolumn{2}{|c|}{ Total }} \\
\hline & & & \multicolumn{2}{|c|}{ Akut } & \multicolumn{2}{|c|}{ Kronis } & & \\
\hline & Abs & $\%$ & Abs & $\%$ & Abs & $\%$ & Abs & $\%$ \\
\hline $0-9 \quad(12)$ & 1 & 8,33 & 0 & 0,00 & 0 & 0,00 & 0 & 0,00 \\
\hline $10-19 \quad(75)$ & 0 & 0,00 & 0 & 0,00 & 0 & 0,00 & 0 & 0,00 \\
\hline $20-29(112)$ & 8 & 7,14 & 0 & 0,00 & 0 & 0,00 & 0 & 0,00 \\
\hline $30-39 \quad(82)$ & 1 & 1,22 & 0 & 0,00 & 0 & 0,00 & 0 & 0,00 \\
\hline $40-49(103)$ & 0 & 0,00 & 0 & 0,00 & 0 & 0,00 & 0 & 0,00 \\
\hline $50-59 \quad(71)$ & 3 & 4,23 & 2 & 2,28 & 0 & 0,00 & 2 & 2,28 \\
\hline$>60$ & 4 & 8,89 & 3 & 6,67 & 0 & 0,00 & 3 & 6,67 \\
\hline Total (500) & 17 & 3,4 & 5 & 1,00 & 0 & 0,00 & 5 & 1,00 \\
\hline
\end{tabular}

riasis hanya didapatkan 2 penderita $(40 \%)$ dengan mikrofilaremia (Lihat Tabel 6).

Pada tabel 6 terlihat diantara 495 orang penduduk yang dalam pemeriksaan tidak menunjukkan kelainan klinis sama sekali, didapatkan 15 orang $(3,03 \%)$ penderita mikrofilaremia positif. Hal ini dapat terjadi sebagai akibat dari interaksi biologik antara mikrofilaria sebagai parasit dengan penderita sebagai hospes.

\section{Kepadatan Rerata Mikrofilaria}

Pada kelompok usia di bawah 20 tahun mikrofilaremia baru $1,1 \%$ (dari 87 orang yang diperiksa) dan dijumpai pada laki-laki. Kepadatan mikrofilaria pada pen- derita kurang dari 20 ekor. Pada kelompok 20-39 tahun, frekuensi meningkat menjadi 4,6\% (dari 194 orang yang diperiksa). Pada laki-laki mikrofilaremia lebih tinggi, 10,3\% (dari 78 orang yang diperiksa) dan pada perempuan $0,8 \%$ (dari 116 orang yang diperiksa). Kepadatan mikrofilaria meningkat kurang nyata, paling tinggi 60-79 ekor pada penderita laki-laki. Pada kelompok usia 40 tahun ke atas, frekuensi mikrofilaremia bahkan turun sedikit menjadi 3,2\% (dari 219 orang yang diperiksa) pada laki-laki menjadi 3,7\% (dari 106 orang yang diperiksa) sedangkan pada perempuan naik menjadi 2,6\% (dari 113 orang yang diperiksa). Kepadatan mikrofilaria cenderung meningkat pada kelompok usia tersebut, paling tinggi di- 
Tabel 4. Penderita Filariasis Akut dan Kronis (Elefantiasis) Menurut Golongan Umur

\begin{tabular}{|c|c|c|c|c|c|c|c|}
\hline \multirow{3}{*}{$\begin{array}{l}\text { Umur } \\
\text { (th) } \\
\text { diperiksa }\end{array}$} & \multirow{3}{*}{ Diperiksa } & \multicolumn{4}{|c|}{ Filariasis klinis } & \multirow{2}{*}{\multicolumn{2}{|c|}{ Total }} \\
\hline & & \multicolumn{2}{|c|}{ Akut } & \multicolumn{2}{|c|}{ Kronis } & & \\
\hline & & Abs & $\%$ & Abs & $\%$ & Abs & $\%$ \\
\hline $0-9$ & 12 & 0 & 0,00 & 0 & 0,00 & 0 & 0,00 \\
\hline $10-19$ & 75 & 0 & 0,00 & 0 & 0,00 & 0 & 0,00 \\
\hline $20-29$ & 112 & 0 & 0,00 & 0 & 0,00 & 0 & 0,00 \\
\hline $30-39$ & 82 & 0 & 0,00 & 0 & 0,00 & 0 & 0,00 \\
\hline $40-49$ & 103 & 0 & 0,00 & 0 & 0,00 & 0 & 0,00 \\
\hline $50-59$ & 71 & 1 & 1,40 & 0 & 0,00 & 1 & 1,40 \\
\hline$>60$ & 45 & 1 & 2,20 & 0 & 0,00 & 1 & 2,20 \\
\hline Total & 500 & 2 & 1,00 & 0 & 0,00 & 5 & 1,00 \\
\hline
\end{tabular}

Tabel 5. Kelainan Klinis pada Penderita Mikrofilaremia Menurut Golongan Umur

\begin{tabular}{|c|c|c|c|c|c|c|c|c|}
\hline \multirow{3}{*}{$\begin{array}{l}\text { Umur } \\
\text { (th) }\end{array}$} & \multirow{3}{*}{$\begin{array}{l}\text { Mikro } \\
\text { filaremia }\end{array}$} & \multirow{3}{*}{$\begin{array}{r}\text { Amikro } \\
\text { filaremia }\end{array}$} & \multicolumn{4}{|c|}{ Dengan Kelainan Klinis } & \multirow{2}{*}{\multicolumn{2}{|c|}{ Total }} \\
\hline & & & \multicolumn{2}{|c|}{ Mikrofilaremia } & \multicolumn{2}{|c|}{ Amikrofilaremia* } & & \\
\hline & & & Abs & $\%$ & Abs & $\%$ & Abs & $\%$ \\
\hline $0-9$ & 1 & 0 & 0 & 0,00 & 0 & 0,00 & 0 & 0,00 \\
\hline $10-19$ & 0 & 0 & 0 & 0,00 & 0 & 0,00 & 0 & 0,00 \\
\hline $20-29$ & 8 & 0 & 0 & 0,00 & 0 & 0,00 & 0 & 0,00 \\
\hline $30-39$ & 1 & 0 & 0 & 0,00 & 0 & 0,00 & 0 & 0,00 \\
\hline $40-49$ & 0 & 0 & 0 & 0,00 & 0 & 0,00 & 0 & 0,00 \\
\hline $50-59$ & 3 & 0 & 1 & 33,30 & 0 & 0,00 & 1 & 33,30 \\
\hline$>60$ & 4 & 0 & 1 & 25,00 & 0 & 0,00 & 1 & 25,00 \\
\hline Total & 17 & 0 & 2 & 11,76 & 0 & 0,00 & 2 & 11,76 \\
\hline
\end{tabular}

*) rata-rata kurang dari 1 ekor per $60 \mathrm{~mm}^{3}$ darah

jumpai pada laki-laki 60-79 ekor.

\section{Pembahasan}

Infeksi Wuchereria bancrofti secara eksklusif di alam telah mengalami evolusi lebih lanjut, lebih adaptif menjadi parasit pada manusia saja, sehingga reaksi penolakan inang tidak keras. Kelainan klinis yang ditimbulkan oleh infeksi W.bancrofti fase akut sangat ringan, terutama di daerah perkotaan. Bahkan di daerah semacam itu kelainan klinis akut umumnya tidak dikeluhkan, tanpa diketahui timbul cacat elefantiasis. Keadaan tersebut kontras dengan infeksi filaria B.malayi (non periodik), reaksi serangan akut demam lebih sering terjadi dan sifatnya berat sehingga penderita tidak bisa melakukan pekerjaan sehari-hari. ${ }^{6}$

Angka tentang endemisitas tersebut dilengkapi oleh hasil pemeriksaan darah jari yang menunjukkan mikrofilaria rate sebesar 3,4\% (17 penderita). Penderita filariasis akut hanya dijumpai pada golongan umur tua (di atas
50 tahun), sedangkan penderita mikrofilaremia yang termuda ditemukan pada usia 9 tahun, sehingga dapat dikatakan sampai sekarang penularan filariasis masih berlangsung. Menurut WHO (1974) dijumpainya penderita yang positif mikrofilaria pada usia muda yakni di bawah 10 tahun merupakan petunjuk yang sensitif masih berlangsungnya penularan filariasis. ${ }^{7}$

Kepadatan rerata mikrofilaria dari hasil survei darah jari di desa Pabean menunjukkan angka rata-rata mikrofilaria per mililiter darah yang dihitung dengan menjumlahkan semua mikrofilaria yang ditemukan pada semua sediaan darah dibagi dengan jumlah orang yang sediaan darahnya positif kemudian dikalikan faktor pengali yaitu $60 \mathrm{~m} 1$ faktor pengali 16,7.8 Sehingga didapatkan kepadatan rata-rata mikrofilaria dalam $1 \mathrm{ml}$ darah sebesar 465,63. Pada tabel 6 menunjukkan penderita yang paling muda ditemukan pada usia 9 tahun sebanyak 1 penderita. Adanya penderita pada usia dibawah 10 tahun ini menunjukkan bahwa penularan masih berlangsung. 
Tabel 6. Penderita Mikrofilaremia Menurut Golongan Umur

\begin{tabular}{|c|c|c|c|c|c|c|c|c|c|}
\hline \multirow{3}{*}{$\begin{array}{l}\text { Umur } \\
\text { (th) }\end{array}$} & \multirow{3}{*}{$\begin{array}{c}\text { Akut } \\
\text { positif }\end{array}$} & \multirow{3}{*}{$\begin{array}{c}\text { Akut } \\
\text { negatif }\end{array}$} & \multirow{3}{*}{ Total } & \multicolumn{4}{|c|}{ Mikrofilaremia } & \multirow{2}{*}{\multicolumn{2}{|c|}{ Total }} \\
\hline & & & & \multicolumn{2}{|c|}{ Akut Positif } & \multicolumn{2}{|c|}{ Akut Negatif } & & \\
\hline & & & & Abs & $\%$ & Abs & $\%$ & Abs & $\%$ \\
\hline $0-9$ & 0 & 12 & 12 & 0 & 0,0 & 1 & 8,3 & 1 & 8,3 \\
\hline $10-19$ & 0 & 75 & 75 & 0 & 0,0 & 0 & 0,0 & 0 & 0,0 \\
\hline $20-29$ & 0 & 112 & 112 & 0 & 0,0 & 8 & 7,1 & 8 & 7,1 \\
\hline $30-39$ & 0 & 82 & 82 & 0 & 0,0 & 1 & 1,2 & 1 & 1,2 \\
\hline $40-49$ & 0 & 103 & 103 & 0 & 0,0 & 0 & 0,0 & 0 & 0,0 \\
\hline $50-59$ & 2 & 69 & 71 & 1 & 50,0 & 2 & 2,9 & 2 & 4,2 \\
\hline$>60$ & 3 & 42 & 45 & 1 & 33,3 & 3 & 7,1 & 3 & 8,9 \\
\hline Total & 5 & 495 & 500 & 2 & 0,4 & 15 & 3,03 & 17 & 3,4 \\
\hline
\end{tabular}

Disamping itu, diketemukannya nyamuk Culex quinquifasciatus yang infektif baik di dalam rumah maupun di luar rumah penduduk merupakan bukti masih terjadinya penularan. ${ }^{7}$

Pengaruh faktor jenis kelamin secara umum dapat dilihat, mikrofilaremia pada laki-laki lebih banyak ditemukan yaitu 4,8\% atau 13 penderita dari 269 penduduk yang diperiksa, sedangkan perempuan hanya didapatkan $1,7 \%$ atau 4 penderita dari 231 penduduk yang diperiksa. Hal ini menunjukkan bahwa risiko penularan lebih tinggi pada laki-laki, baik dari keberadaan mikrofilaria tetapi tidak kepadatannya. Dilihat dari kepadatan mikrofilaria didapatkan jumlah mikrofilaria tertinggi sebanyak 72 ekor dalam $60 \mathrm{~mm}^{3}$ darah. Kepadatan mikrofilaria tertinggi yang relatif masih rendah tersebut didapatkan pada penderita laki-laki. Penularan lebih banyak atau lebih intensif pada laki-laki tidak terlepas dari pemaparan yang lebih banyak pada gigitan nyamuk vektor filaria. Hal ini seiring dengan penelitian dari Sujadi, ${ }^{9}$ tentang Filariasis di beberapa daerah endemik di Kalimantan Timur.

\section{Kesimpulan}

Filariasis limfatik di Kota Pekalongan tepatnya di Kelurahan Pabean Kecamatan Pekalongan Utara disebabkan oleh cacing filaria W.bancrofti dengan angka mikrofilaria yang tinggi. Angka kesakitan akut filariasis limfatik yaitu adanya gejala limfangitis yang tidak jelas disertai dengan demam, sakit kepala dan lemah tinggi dan kesakitan kronis tidak ada. Rata-rata kepadatan mikrofilaria tinggi.

\section{Saran}

Kepada Dinas Kesehatan Kota Pekalongan perlu melakukan pengobatan masal dengan dosis standar pada semua penduduk usia $>2$ tahun serta meningkakan surveilans untuk memantau penularan serta meningkatkan kerjasama lintas program dan sektoral untuk sosialisasi filariasis di Kota Pekalongan. Pemerintah daerah perlu menyediakan dana operasional pengobatan masal, pemberdayaan masyarakat untuk meningkatkan perilaku hidup bersih dan sehat. Untuk peneliti perlu mengembangkan efektifitas pemakaian DEC dalam pengobatan masal.

\section{Daftar Pustaka}

1. Michael E, Malecela M, Zervos M, Kazura J. Global eradication of lymphatic filariasis: the value of chronic disease control in parasite elimination programmes. Plosone Open Acess. 2008; 3(8): e2936.

2. Departemen Kesehatan RI. Epidemiologi filariasis. Jakarta: Ditjend PP\&PL; 2005.

3. Dinkes Kota Pekalongan. Laporan Tahunan 2005. Pekalongan: Dinkes Kota Pekalongan; 2005.

4. Departemen Kesehatan RI. Pedoman penentuan daerah endemis penyakit kaki gajah 2002. Jakarta: Departemen Kesehatan RI; 2002.

5. Pemerintahan Kota Pekalongan. Laporan buku monografi kelurahan pabean tahun 2006. Pekalongan: Pemerintahan Kota Pekalongan; 2006.

6. Departemen Kesehatan RI. Eliminasi penyakit kaki gajah di Indonesia 2001. Jakarta: Departemen Kesehatan RI; 2001.

7. Palumbo E. Filariasis: diagnosis, treatment and prevention. Acta Biomed. 2008; 79: 106-9.

8. Departemen Kesehatan RI. Pedoman penentuan dan evaluasi daerah endemis filariasis. Jakarta: Ditjen PP \& PL; 2005.

9. Sudjadi, F.A. Filariasis di beberapa daerah endemik di Kalimantan Timur, kajian intraspesifik brugia malayi penyebab penyakit dan beberapa aspek epidemiologinya [disertasi]. Yogyakarta: Universitas Gadjah Mada; 1996. 